\title{
How to Fix Carbon Dioxide Same Amount as Emission for the Protection of Global Warming
}

\author{
Shoichiro Ozaki* \\ The Institute of Physical and Chemical Research, Japan \\ *Corresponding author: Shoichiro Ozaki, Japan

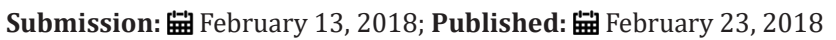

\begin{abstract}
Fossil fuel is burned releasing $\mathrm{CO}_{2}$ and heart. Released $\mathrm{CO}_{2}$ is fixed by plant by $\mathrm{CO}_{2}$ assimilation reaction absorbing heart. Burning reaction is reverse reaction of $\mathrm{CO}_{2}$ assimilation. If we can compensate the generation of $\mathrm{CO}_{2}$ and heart of burning with the absorption of $\mathrm{CO}_{2}$ and heart by $\mathrm{CO}_{2}$ assimilation, global warming will be protected.
\end{abstract}

Keywords: $\mathrm{NOx} ; \mathrm{CO}_{2} ; \mathrm{CO}_{2}$ assimilation; Global warming; Paris agreement; Plankton

\section{Mini Review \\ $\mathrm{CO}_{2}$ is increasing $2.0 \mathrm{ppm}$ annually. Total amount of $\mathrm{CO}_{2}$ in the world is $2.83 \times 1012$ tone. Total emission of $\mathrm{CO}_{2}$ in one year is $3.6 \times 1010$ tone. Almost all $\mathrm{CO}_{2}$ is used for $\mathrm{CO}_{2}$ assimilation of plant. This means that all $\mathrm{CO}_{2}$ in the world is replaced by new $\mathrm{CO}_{2}$ in 7.8 years. Increase of $\mathrm{CO}_{2}$ in one year is $2.83 \times 1012 \times 2 / 400=1.415 \times$ 1010 tone (142 billion tones). Therefore $3.6 \times 1010-1.42 \times 1010$ $=2.18 \times 1010$ tone, 218 billion tones $\mathrm{CO}_{2}$ is fixed in one year. If we can increase the fix of $\mathrm{CO}_{2} 1.41 \times 1010$ tone in year we can protect global warming. When fossil is burned, NOx is produced about $1 / 25$ of produced $\mathrm{CO}_{2}$. The ratio $\mathrm{C} / \mathrm{N}=25 / 1$ is same as plant composition ratio $\mathrm{C} / \mathrm{N}=25 / 1$. Plant eat $\mathrm{CO}_{2}$ and nutrient $\mathrm{N}$ by the ratio $\mathrm{C} / \mathrm{N}=25 / 1$. 14.4 billion tones NOx is estimated to be produced when 360 billion tone $\mathrm{CO}_{2}$ is produced.}

Many governments consider NOx as pollution gas and eliminating NOx by the reaction with ammonia. Amount of NOx is so much, $\mathrm{CO}_{2}$ assimilation is retarded very much. $\mathrm{CO}_{2}$ fixing is retarded very much. And global warming is accelerated very much. For the production of ammonia, much fossil is used and much $\mathrm{CO}_{2}$ is produced and global warming is accelerated so fast. $70 \%$ of earth is covered by sea. $70 \%$ of $\mathrm{CO}_{2}$ assimilation is carried out at sea. 16 billion years ago, fish was not appeared. Plankton grow and oil is formed as fossil of plankton. Plankton grows infinitively when nutrient $\mathrm{N}$ and $\mathrm{P}$ is present at any condition.

Sea water contains much $\mathrm{N}$ and $\mathrm{P}$. These $\mathrm{N}$ and $\mathrm{P}$ are consumed by plankton and concentration of N,P at the surface became poor. Fish appeared at around 15 billion years ago. Fish grow by eating plankton. Fish grow at plankton rich, NP rich sea. World fish industry and $\mathrm{CO}_{2}$ fixing changed very much since 1980 by the supply of NOx produced by burning of fossil.
World fish production in 2016 increased to 200 million tone, about double of 93 million tons in 1997. China, Indonesia, India, Vietnam do not eliminate NOx and do not do drainage treatment They use NOx and excreta as it is for production of plankton and fish. Therefore fish production increased remarkably at the district where no N,P supply by counter current of nutrient rich deep sea water with nutrient poor shallow sea water. China produced 16.77 million tone fish in 2002 and 79.38 million tone fish in 2016. This is huge Increase.

China produced 4 billion tones NOx. This NOx is released to air and dissolved in rain and give enough nutrient nitrogen to sea, lake and river to grow 16 billion tone plankton and 79.38 million tone fish .This 4 billion tone NOx became enough fertilizer for the production of 4.4 billion tone grain. And also this 4 billion tone NOx contributed for the growth of tree and grass. These three $\mathrm{CO}_{2}$ assimilation action, plankton formation, grain production tree and grass growth, fixed 100 billion tones $\mathrm{CO}_{2}$. The amount of NOx produced is around 14.4 billion tone in whole world.

\section{Conclusion}

To eliminate NOx 14.4 billion tone, ammonia 8.6 billion tone is used. To make ammonia 8.6 billion tone, 1.44 billion tone hydrogen gas is used. To make 1.44 billion tone hydrogen. Butan, 8.3 billion tone is used. As the result 25.3 billion tone $\mathrm{CO}_{2}$ is released. If $\mathrm{NOx}$ elimination is stopped, 25.3 billion tone $\mathrm{CO}_{2}$ release can be stopped and $14.4 \times 25=360$ billion tone $\mathrm{CO}_{2}$ can be fixed. Therefore if we stop the elimination of NOx, and stop the elimination of N,P in drain, we can stop the global warming. 
Creative Commons Attribution 4.0

International License

For possible submissions Click Here

\section{Your subsequent submission with Crimson Publishers} will attain the below benefits

- High-level peer review and editorial services

- Freely accessible online immediately upon publication

- Authors retain the copyright to their work

- Licensing it under a Creative Commons license

- Visibility through different online platforms

- Global attainment for your research

- Article availability in different formats (Pdf, E-pub, Full Text)

- Endless customer service

- Reasonable Membership services

- Reprints availability upon request

- One step article tracking system 